\title{
Ecosystem Services for a Sustainable Energy Policy in Bosnia and Herzegovina
}

\author{
L. A. Mesbah
}

\begin{abstract}
This paper examines the concept of ecosystem services for a sustainable energy policy, and briefly analyses of current and possible energy sources in Bosnia and Herzegovina (BiH). BiH remains an important cosumer of fossil fuel energies, using both domestic (coal) and imported (petrol and gas) resources. $\mathrm{BiH}$ is also using renewable energy sources such as hydropower for electricity production and biomass mainly for heating and has strong potential to further develop other renewable sources of energies. It remains essential but also challenging for the country's strategy to further develop sustainable energy resources while maintaining functional ecosystems as an important natural capital .
\end{abstract}

Keywords-Ecosystem Services, Sustainable Development, Energy, Renewable Energy, Climate Change, Policy, Bosnia and Herzegovina.

\section{INTRODUCTION}

$\mathrm{E}$ VERY ecosystem on planet earth fuctions thanks to an input of energy transferred from the sun into the planet earth system that comprises the atmosphere, the hydrosphere and the biosphere. Solar energy, or solar radiations are tranferred to the primary producers (photosynthesis) that provide food (or energy) to the chain of consumers in the ecosystem. This food chain is actually a food web and is a part of the energy transfer where matter is being recycled (the water cycle, carbon, nitrogen, phosphore, sulfur, etc..) and renewed by the decomposers and detritus feeders hailing from the a rich biodiverse ecosystem. What can we learn from ecosystems in terms of energy and its sustainable use ? What kind of resource or services can ecosystems provide us with? What are the oportunities in BIH and the Balkans for a sustainable use of Ecosystem Services?

L. A. MESBAH is with the American University in Bosnia and Herzegovina, Fra Anđela Zvizdovića 1, 71000 Sarajevo, Bosnia and Herzegovina, (E-mail: 1mesbah@aubih.edu.ba)

\section{BASIC CONCEPTS}

The concept of Ecosystem Services has been defined and outlined at the Millennium Ecosystem Assesment in 2005 (MEA, 2005):

"An ecosystem is a dynamic complex of plant, animal, and microorganism communities and the nonliving environment interacting as a functional unit. Humans are an integral part of ecosystems. Ecosystems vary enormously in size; a temporary pond in a tree hollow and an ocean basin can both be ecosystems. Ecosystem services are the benefits people obtain from ecosystems. These include provisioning services such as food and water; regulating services such as regulation of floods, drought, land degradation, and disease; supporting services such as soil formation and nutrient cycling; and cultural services such as recreational, spiritual, religious and other nonmaterial benefits."

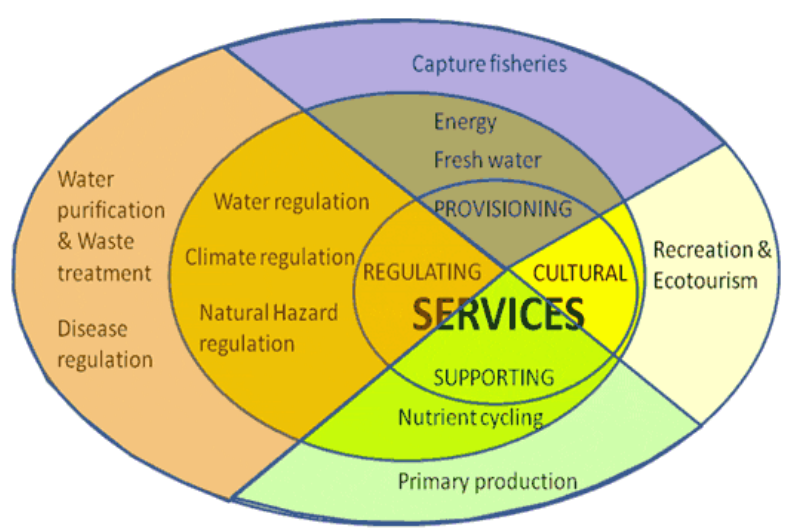

Fig. 1. Schematic description of Ecosystem Services (UNEP and MEA,2005)

Key Definitions as defined by the Ecosystem Millennium Assessment:

Ecosystem. An ecosystem is a dynamic complex of plant, animal, and microorganism communities and the nonliving environment interacting as a functional unit. Humans are an integral part of ecosystems. Ecosystems 
vary enormously in size; a temporary pond in a tree hollow and an ocean basin can both be ecosystems.

Ecosystem services. Ecosystem services are the benefits people obtain from ecosystems. These include provisioning services such as food and water; regulating services such as regulation of floods, drought, land degradation, and disease; supporting services such as soil formation and nutrient cycling; and cultural services such as recreational, spiritual, religious and other nonmaterial benefits.

Well-being. Human well-being has multiple constituents, including basic material for a good life, freedom of choice and action, health, good social relations, and security. Well-being is at the opposite end of a continuum from poverty, which has been defined as a "pronounced deprivation in well-being." The constituents of well-being, as experienced and perceived by people, are situation-dependent.

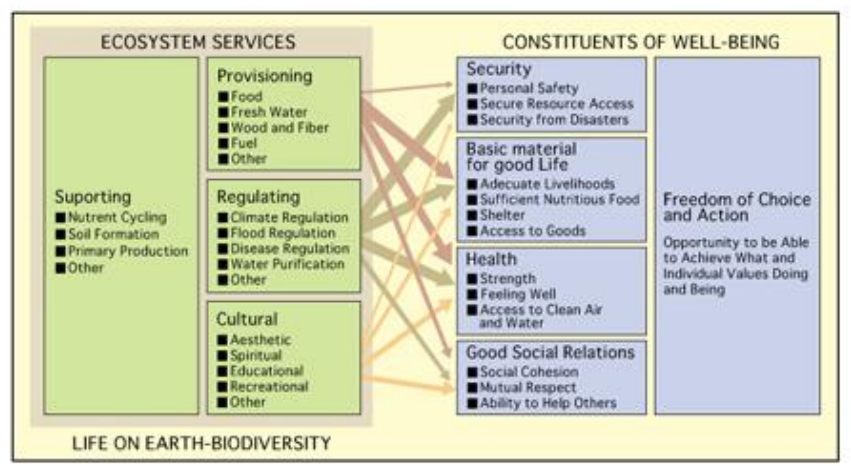

Fig.2. Ecosystem Services providing constituent of human well being (MEA, 2005)

Among supporting services, primary production is essential in making available provisioning services for humanity. The biomass produced becomes then a source of food, wood fiber or fuel. Fossil fuels are also among provisioning services but their life cycle is much longer than food or even wood production. Because of their much longer lifetime at the human time scale, fossil fuels, including petrol, coal and gas, are not considered renewable. Renewable energy sources are increasingly considered important in societies moving towards a post industrial phase. Oil remains the largest source of energy world wide after coal, both fossil fuels, but most experts agree that global peak of oil production have been passed and that it will become increasingly difficult and costly to extract fossil fuels from the underground (Larry Staudt, 2011).

Some of the provisioning services are considered to be a source of energy: Food, fuel and freshwater. With the exception of geothermal, seismic and lunar, energy resources on the planet earth are directly or indirectly solar energy sources. As a result of a constant increase of burning fossil fuel as a source of energy since the industrial revolution, global concentrations of carbon dioxide and their combustion products are steadily increasing.

As clearly outlined and explained in the fourth assessment report of the International Panel on Climate Change (IPCC, 2007), it is the first time in history that human activities have been shown to be responsible for climate change at a global scale. Global warming has consequences in regional climate patterns and distributions, therefore also on human economic, social activities and political decisions. The same report indicated with a high degree of confidence that global warming of atmospheric temperature is due to an increased emission of anthropogenic Green House Gases (GHG) (IPCC, 2007). These gases include mainly carbon dioxide $\left(\mathrm{CO}_{2}\right)$ released in the atmosphere after burning fossil fuels but also Methane $\left(\mathrm{CH}_{4}\right)$, Nitrate Oxides $\left(\mathrm{NO}_{\mathrm{X}}\right)$ and other anthropogenic strong GHGs such as $\mathrm{PFC}$ and $\mathrm{SF}_{6}$. The greenhouse effect is storing the heat produced by the sun radiations during the day and keeps the earth's temperature at a level comfortable for life on earth to strive. These greenhouse gases that are released after combustion of fossil fuels as part of the carbon, Nitrogen or water cycle. The speed of accumulation of these gases into the atmosphere is higer that the capacity of the ecosystems to recycle.

A sustainable aproach to meet the needs of an increasing demand for energy, can only be met with a sustainable supply of energy, or renewable sources of energy. Following the post war recovery and reconstruction, and despite a weak industry, $\mathrm{BiH}$ has been facing an increasing need for energy.

What are the sources of energy in BiH? Which Ecosystem Services can be a source of renewable source of Energy in BiH? Hydropowers, Biomass, Wind energy, Solar or Geothermal are possibilities. Which one has been developed and which has the most potential for further development? What can be the consequences for the environment and their ecosystems?

\section{MATERIALS AND METHODS}

This study is a short review. It is therefore the result of desktop research and gathering of information in previous publications and research, and policy documents. The review also reflects a number of discussions and presentations that took place in seminars, and conferences in which the author took part in recent years.

\section{RESULTS AND DISCUSSION}

\section{A. Services provided by Ecosystems in BiH.}

Ecosystems in $\mathrm{BiH}$ are quite diverse due to a large variety of climates and rich topography, from the Mediterranean costal areas, to the semi Mediterranean with mountain influence, the high alpine influence and the continental with the whole range of intermediaries (Mesbah, 2009, 2012). This large variety of climatic conditions 
together with a geological diversity creates conditions for a variety of ecosystems which include Mediterranean, deciduous forest, coniferous forests, alpine, even artic at higher elevations. Wetlands can also be found in lowlands, near rivers. These ecosystems provide a large number of services including arable soil for agriculture, wood and non wood products from forests, freshwater, etc... as presented on Fig. 2.

\section{B. Renewable energy in BiH}

$\mathrm{BiH}$ is dependent on fossil fuels such as petrol and gas imported from outside, but has its own coal reserves (Mesbah, 2009). Electric energy is produced in $\mathrm{BiH}$ by hydroelectric power as well as thermoelectric (coal) power plants. In 2008, the total of energy in $\mathrm{BiH}$ from renewables was $9.6 \%$ of the total consumption of energy (including tranports), which is low compared to the previous 20 years (UNEP, State of the environment report o be published in 2013). Globally around $13 \%$ of the total enegy use come from renewable sources, or $87 \%$ come from non renewable sources (International Energy Agency, World Watch Institute).

Among usage of renewable energy, roughly half comes from Biomass (mainly wood) the other half from Hydropower. A very small portion is represented by Goethermal $0.04 \%$ ( UNEP, 2013)

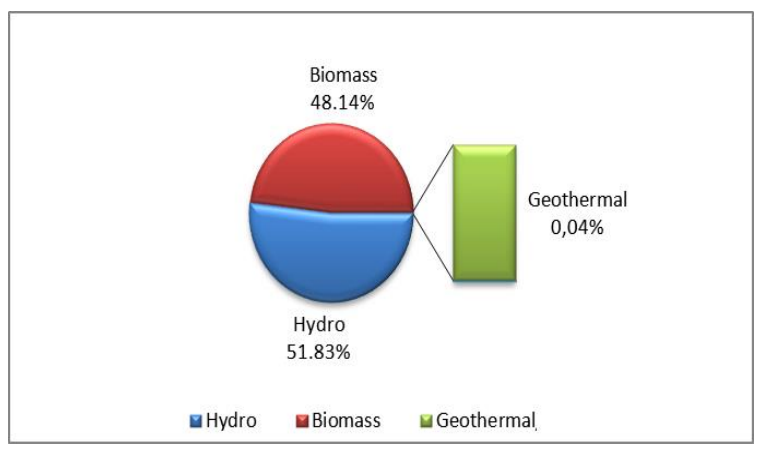

Fig.3. Energy consumption from renewable sources by energy source in Bosnia and Herzegovina, in percentages for 2008 (UNEP, state of the environment report, 2013)

\section{Climate Change and Energy}

Globale climate change has been shown to be linked with an increasing global emission of green house gaz from anthropogenic burning of fossil fuels. Global climate change is also affecting $\mathrm{BiH}$, with a trend for hotter and dryer summers, milder and shorter winters (Mesbah, to be published in 2013 by UNEP, and Initial National Communication of $\mathrm{BiH}$ to the UNFCCC, 2011). In absolute number $\mathrm{BiH}$ is not a major emitter of GHG, but it has a relatively high number per capita (UNEP, 2013), and it could be significantly reduced by using more renewable sources of energy and improving energy efficiency.

\section{Biomass}

Other potentials for renewable energy in $\mathrm{BiH}$ include wind energy and non-crop biogas such as wood production in sustainable forestry and agriculture practices. New generation of technologies (ethanol produced from cellulose for example) provide an efficient and economically viable production of bioenergy from biomass obtained from sustainable forestry and meadows management instead of getting biomass from crops which competes with food production over land and water. $\mathrm{BiH}$ needs to benefit from these new technologies for bio energy production. Sustainable forestry and agriculture management provides not only significant sources for sustainable energy, it contributes to $\mathrm{CO} 2$ sequestration through photosynthesis, but it can also provide habitat and shelter to maintain biodiversity, potential for cultural value and eco-tourism, and a sustainable economy.

Biomass usage includes burning wood but also organic wastes that are part of Municipal Land fills. Sarajevo City Landfill in Smiljevići, Sarajevo Canton has been using its gaz rpoduction due to fermentation of organic wastes since 2001. The output capacity of this plant is $0.35 \mathrm{MW}$ with potential annual production of electrical energy of 0.52 GWh (UNEP and State Ministry of Foregn Tarde of BiH, 2013). Cattle manure can also be used as a biomass. In some countries it is stored for the production of biogas, which can be burned to produce heat and electricity. Grass is an other example of sustianable biomass, produced from perenial plants without much agriculture land management.

\section{E. Hydropower}

Hydropower is well developed in $\mathrm{BiH}$ with $40 \%$ of total electric production in the country but has still strong potential for additional development, as it is one of the less developped Hyrdopower system in the world compared to its potential (aournd $35 \%$ i sactually used (UNEP and State Ministry of Foregn Tarde of $\mathrm{BiH}, 2013)$. BiH is mainly mountainous land and supplied with sufficient water flowing through streams and rivers with the current climate. Additional development of power plants is taking place having to take into account environmental as well as social concerns.

\section{F.Wind energy}

Bosnia and Herzegovin also has a significant potential for wind energy. Locations with high potential have been indentified and the install capacity being estimated (Ministry of Energy, Mining and Industry of Federation Bosnia and Herzegovina, 2010) UNEP and State Ministry of Foregn Tarde of $\mathrm{BiH}$ to be published in 2013).

\section{G. Solar Energy in BiH}

Due to its geographic location $\mathrm{BiH}$, compared to other places in Europe, the number of days with sun (especially in Herzegovina) is higer the average in europe. $\mathrm{BiH}$ therefore has a has a strong potential for the development of solar energy, but is very little developed. CRP, an NGO from Tuzla indicates that, installing a solar pannel on the roof of a priate house could save the household $50 \mathrm{KM}$ a month for their electricity bill (CRP, 2012). An other project indicates the strong potential in Herzegovina with a project in Grude, Herzegovina. 


\section{H. Energy saving}

Energy intensity is the amount of energy used compared to the country' s GDP. With a low GDP and a significant amount of energy wasted, BiH has a High Energy Intensity, around 4 times higher than other countries in the western Balkan (EEA, 2010, UNEP, 2013). During the yougoslavia time, BiH already had a much higer energy intensity than other republics of the yougoslavian federation, because of the large number of heavy industries compered to a relatively low population.

$\mathrm{BiH}$ still has much progress to make in energy saving measures, including those needed for transport, housing and general efficiency of infrastructure development, maintenance. Many public and private buildings need to be renovated or re-built in order to meet higher standards of energy saving measures. Standardization of more efficient electricity-dependent equipment should be put in place. New policies should aim at moving towards the use of renewable energies in the transport sector which still relies significantly on fossil fuel. $\mathrm{BiH}$ is still strongly dependent on imports of fossil fuel such as petrol and gas, but needs to move further towards an increasing use of renewable energy such as bioenergy as well as hydropower, key elements for a sustainable future of the country but also for the preservation of its natural environment.

\section{CONCLUSION}

Thanks to a rich topography and a combination of continental and Mediterranean climates, BiH offers many services from a rich variety of biodiversity and ecosystems. Among services provided by these ecosystems are renewable forms of energy. Renewable energy represents an important source of energy with additional potential especially in hydropower for electricity. Still in $\mathrm{BiH}$ only around $9 \%$ of total energy consumption comes from renewable sources. Biomass and hydropower represent an important potential for further development, but other energy sources have also room development such as Wind energy, Geothermal and Solar Energy.

Recommendations for energy policies have been prepared by the State of the Environment report published in 2013: These recommendations include the adoption of regulations for energy efficiency in buildings, and introduce a system of label or certificates in the energy efficiency of buildings. In additon a system of incentives to increase energy efficiency in households and industry is needed. Replacing imported fossil fuels with energy from domestic renewable sources would contribute to more independency for the country but also to reduce green house gas emissions.

The energy sector in Bosnia and Herzegovina is key for economic development, but needs to grow while maintaining functional ecosystems, in order to maintain the services they provide.
Such a balance between development and sustaning functional ecosystems needs to be taken into account when developping strategies and policies in the energy sector but also in other sectors of the country strategies. Policies aimed at encouraging the use of renewable energy include Clean Development Mechanism (UNFCCC, 2013, National focal point in $\mathrm{BiH}$ ), an international financial mechanism meant to reduce greenhouse gases from burning of fossil fuels and encourage investments in renewable energies.

\section{ACKNOWLEDGMENT}

The study is selected from International Symposium on Sustainable Development, ISSD 2013.

\section{REFERENCES}

[1] CRP, NGO based in Tuzla, Bosnia and Herzegovina (2012): the Power of solar energy

http://zastitaokolisa.crp.org.ba/index.php?option=com content\&view=arti cle\&id=185\%3Asnaga-sunceveenergije\&catid $=3 \% 3$ Aaktuelnosti\&Itemid $=139 \&$ lang $=e n$

[2] Green Rhino Energy (2013) Solar Photovoltaic project in Bosnia and Herzegovina last access in March 2013 http://www.greenrhinoenergy.com/projects/bih/

[3] European Environmnetal Agency (EEA) (2010) Total energy intensity http://www.eea.europa.eu/data-and-maps/indicators/total-energy-intensityoutlook-from-eea

[4] International Energy Agency (2013) http://www.iea.org/

[5] IPCC (2007) Fourth Assesment Report of the The international Panel on Climate Change (IPCC) 4AR http://www.ipcc.ch/publications and data/ar4/syr/en/spms1.html

[6] Millennium Assessment Recommendations (MEA) (2005) available at:

[7] http://www.millenniumassessment.org/en/Reports.aspx.

[8] Larry Staudt (2011). Recent Nuclear emergencies, whilst aiming for a sustainable energy future. EBBF publication available at: http://ebbf.org/blog/recent-nuclear-emergencies-whilst-aiming-for-asustainable-energy-future/

[9] L. A. Mesbah (2013) The State of the Environment in BiH UNEP and State Ministry of Foregn Tarde of BiH, 2013 ( as Co-author) http://www.unep.ba/soer-data-survey.html.

[10] L.A. Mesbah (2012) Presentation of the Situation in Bosnia and Herzegovina at the EC Workshop on April 18-20, 2012 on Ecosystem Services mapping and assessment of EU enlargement and integration countries, at the Joint Research Center of the European Comission, Ispra Italy. http://ies.jrc.ec.europa.eu/index.php?page $=81$

[11] L.A. Mesbah (2009): Ecosystem services for sustainable development in $\mathrm{BiH}$ and the Balkans, UNEP/University of Geneva available at http://www.unige.ch/formcont/environmentaldiplomacy/TheseMesbahLau rent.

[12] R.Costanza et al (1997) The value of the world's ecosystem services and Natural Capital Nature 387, 253 - 260.

[13] http://www.nature.com/nature/journal/v387/n6630/abs/387253a0.html.

[14] Sutward Chapin, Pamela A. Matson, Peter M. Vitousek (2011).The principles of Terestrial Ecosystems, Springer, $529 \mathrm{p}$.

[15] UNFCCC (2013) Clean development mechanism of the UN Framework Convention on Climate Change http://cdm.unfccc.int/ and http://www.unfccc.ba/en/unfecc/national-communication and http://www.unfccc.ba/ba/posljednje/novosti/21-bih-adopts-the-initialnational-communication-under-the-united-nations-framework-conventionon-climate-change. 


\section{BIOGRAPHY}

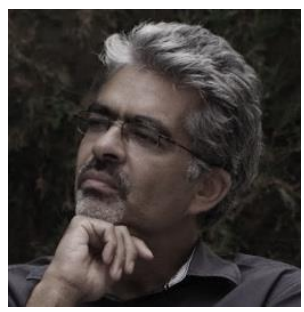

LAURENT AMINE MESBAH was born in France. He received a B.Sc and a M.Sc from the University of Strasbourg in 1991 and 1993 and completed his $\mathrm{PhD}$ in Plant Biology in 2000 at the Free University in Amsterdam, the Netherlands. In 2009, he completed a Certificate of Advanced Studies in Environmental Diplomacy at the University of Geneva. Since 2011, L.A. Mesbah is Associate Professor of Environmental Sciences at the American University in $\mathrm{BiH}$ and an expert consultant with International Organizations on environmental issues and climate change in the Balkans and other regions of the world. 